\title{
SERUM IMMUNOGLOBULINS IN JUVENILE RHEUMATOID ARTHRITIS
}

\author{
BY \\ V. HOUBA AND R. BARDFELD \\ From the Research Institute of Rheumatic Diseases, Prague, Czechoslovakia. \\ (Director: Prof. F. Lenoch, M.D., D.Sc.)
}

Juvenile rheumatoid arthritis (JRA) differs in many aspects from its adult counterpart (Edström, 1958); one of the differences is a low incidence of positive sero-reactions for rheumatoid factors (RF) in patients with JRA (Bywaters, Carter, and Scott, 1959; Sievers, Ahvonen, Aho, and Wager, 1963; Ansell, 1966). Although the agglutinating activity of RF was found in different classes of immunoglobulins (IgC, IgA, IgM), the typical representative of RF is IgM (McCormick, 1966). However, there is no direct correlation between the IgM values and the presence or absence of RF in the serum of patients with rheumatoid arthritis (Claman and Merrill, 1966; Barden, Mullinax, and Waller, 1967; Marcolongo, Carcassi, Frullini, Bianco, and Bravi, 1967).

The purpose of this paper was to study the serum levels of immunoglobulins (IgG, IgA, IgM) and to compare them with serological RF-positivity in the serum of patients with JRA.

\section{Material and Methods}

Sera were obtained from 47 patients with JRA, of whom 46 were aged 4 to 26 years and one was aged 45 years (mean 17), and from twelve healthy young subjects aged 7 to to 15 years (mean 12.5). The patients all fulfilled the diagnostic criteria for definite JRA (Ansell and Bywaters, 1963).

Immunoglobulins in all sera were determined by the technique of Fahey and McKelvey (1965), using the commercial antisera to IgG, IgA, and IgM and the related reference proteins (Institute of Vaccine and Sera, Prague, Czechoslovakia). Most of the sera were retested by the use of Hyland-immunoplates (Hyland Laboratories, U.S.A.). There were no significant differences in the immunogloblin levels obtained by the two techniques used.

All sera were tested for RF by the latex-fixation and the sensitized sheep cell agglutination tests (Houba and Allison, 1966). The negative control sera and the First Reference Preparation for rheumatoid arthritis serum
(W.H.O., 1966, 1967) were included in all estimations of RF.

Potencies of sera in the latex-fixation and sensitized sheep cell agglutination tests were expressed as a percentage of the results with the Reference Preparation: potencies higher than 5 per cent. were regarded as RFpositive, lower potencies as RF-negative.

\section{Results}

The immunoglobulin levels $(\mathrm{mg} . / \mathrm{ml}$.) are shown in Fig. 1. The mean and range of the levels in healthy subjects are shown by horizontal lines and the levels in the 47 patients with JRA by individual points.

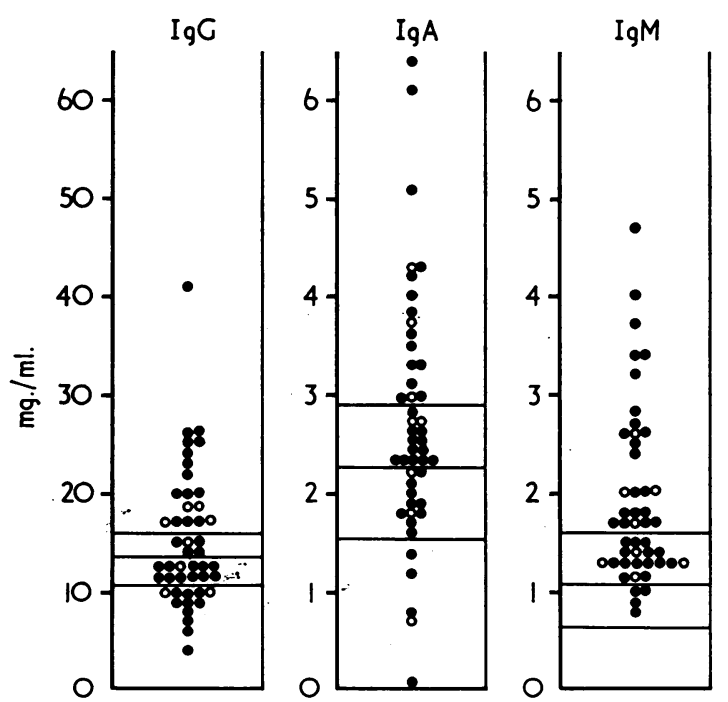

Fig. 1.-Serum levels of immunoglobulins in 47 cases of juvenile rheuatoid arthritis. 8 RF positive $\bigcirc$, and 39 RF negative 0 . Mean and range of values for control subjects are shown by horizontal lines.

The mean values for healthy subjects (IgG $13 \cdot 0$; IgA $2 \cdot 27 ; \operatorname{IgM} 1 \cdot 05)$ are in agreement with the 
findings of Fahey and McKelvey (1965), Claman and Merrill (1966), Marcolongo and others (1967), and Rowe, McGregor, Smith, Hall, and Williams (1968) for adult control subjects, and also with the data of Collins-Williams, Tkachyk, Toft, and Moscarello (1967) for children (except the IgA values).

Among our series of 47 patients with JRA, 53 per cent. had raised values of IgM, 34 per cent. raised IgG levels, and 36 per cent. raised IgA levels. The mean values (mg./ml. serum) in the patients' sera were $15 \cdot 2$ for IgG, 2.72 for IgA, and 1.92 for IgM. The results were not age dependent.

RF-positivity was distributed equally in cases with raised and in those with normal immunoglobulin levels. Decreased IgG and IgA levels

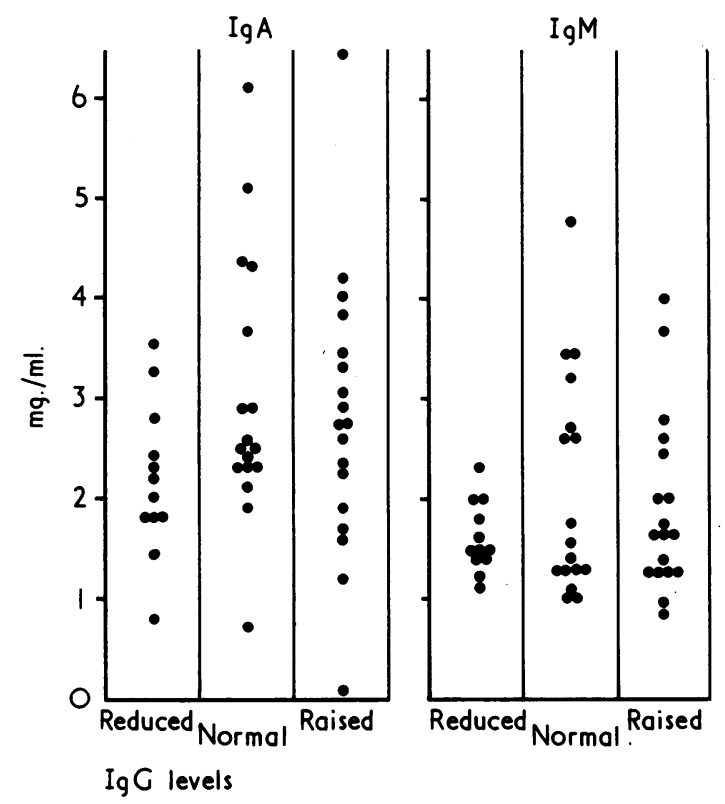

Fig. 2.-Serum levels of $\operatorname{IgA}$ and $\operatorname{IgM}$ in 47 cases of juvenile rheumatoid arthritis with reduced (12) normal (17), and raised (18) levels of IgG. were found in some patients. The serum levels of IgA and IgM in patients with reduced, normal, and raised levels of IgG are shown in Fig. 2. As in the results of Cassidy and Burt (1967), a single case of IgA deficiency was observed.

It seems that there is no striking difference in immunoglobulin levels (IgG, IgA, and IgM) between the patients with JRA described here and adult patients with rheumatoid arthritis reported by various authors, although the serological positivity for RF has been found to be significantly lower in JRA patients (Bywaters and others, 1959; Ansell, 1966; Claman and Merrill, 1966; Marcolongo and others, 1967).

\section{Summary}

Increased levels of immunoglobulins were found in the sera of 47 patients with juvenile rheumatoid arthritis (IgG in 34 per cent., IgA in 36 per cent., and IgM in 53 per cent. of patients respectively) when compared with the levels in twelve healthy subjects. The distribution of sero-positivity for rheumatoid factors in patients with juvenile rheumatoid arthritis was the same in those with raise 8 immunoglobulin levels as in those with normat values.

We are indebted to Ing. F. Skvaril (Institute of Vaccine and Sera, Prague, Czechoslovakia) for antises a and reference standards of immunoglobulins which were analysed by Dr. J. L. Fahey (Reference Center for $\overrightarrow{\overrightarrow{0}}$ Immunoglobulins, National Cancer Institute, National 응 Institutes of Health, Bethesda, Md, U.S.A.); to Dr. S. G. Anderson (Division of Biological Standards, National Institute for Medical Research, London, England) for the Reference Preparation for rheumatoid arthritis serum; and to Dr. E. J. Holborow (M.R.C. Rheumatism Research Unit, Canadian Red Cross Memorial Hospital, Taplow) for helpful criticism.

\section{REFERENCES}

Ansell, B. M. (1966). In "Modern Trends in Rheumatology", ed. A. G. S. Hill, p. 18. Butterworths, London.

and Bywaters, E. G. L. (1963). Pediat. Clin. N. Amer., 10, 921 (Rheumatoid arthritis (Still's disease), in Symposium on Collagen Diseases).

Barden, J., Mullinax, F., and Waller, M. (1967). Arthr. and Rheum., 10, 228 (Immunoglobulin levels in rheumatoid arthritis).

Bywaters, E. G. L. Carter, M. E., and Scott, F. E. T. (1959). Ann. rheum. Dis., 18, 225 (Differential agglutination titre in juvenile rheumatoid arthritis).

Cassidy, J. T., and Burt, A. (1967). Arthr. and Rheum., 10, 272 (Isolated IgA deficiency in juvenile rheumatoid arthritis). 
Claman, H. N., and Merrill, D. (1966). J. Lab. clin. Med., 67, 850 (Serum immunoglobulins in rheumatoid arthritis).

Collin-Williams, C., Tkachyk, S. J., Toft, B., and Moscarello, M. (1967). Int. Arch. Allergy, 31, 94 (Quantitative immunoglobulin levels (IgG, IgA, and IgM) in children).

Edström, G. (1958). Arthr. and Rheum., 1, 497 (Rheumatoid arthritis and Still's disease in children).

Fahey, J. L., and McKelvey, E. U. (1965). J. Immunol., 94, 84 (Quantitative determination of serum immunoglobulins in antibody-agar plates).

Houba, V., and Allison, A. C. (1966). Lancet, 1, 848 (M-antiglobulins (rheumatoid-factor-like globulins) and other gamma-globulins in relation to tropical parasitic infections).

Marcolongo, R., Jr., Carcassi, A., Frullini, F., Bianco, G., and Bravi, A. (1967). Ann. rheum. Dis., 26, 412 (Levels of serum immunoglobulins in patients with rheumatoid arthritis).

McCormick, J. N. (1966). In "Modern Trends in Rheumatology", ed. A. G. S. Hill, p. 163. Butterworths, London.

Rowe, D. S., McGregor, I. A., Smith, S. J., Hall, P., and Williams, K. (1968). Clin. exp. Immunol., 3, 63 (Plasma immunoglobulin concentrations in a West African (Gambian) community and in a group of healthy British adults).

Sievers, K., Ahvonen, P., Aho, K., and Wager, O. (1963). Rheumatism, 19, 88 (Serological patterns in juvenile rheumatoid arthritis).

W.H.O. (1966). "Expert Committee on Biological Standardization", 18th Report. W.H.O. tech. Rep. Ser., No. 329, p. 20.

- (1967). Idem, 19th Report. W.H.O. tech. Rep. Ser., No. 361, p. 94.

Les immunoglobulines sériques dans 'la polyarthrite rhumatoïde juvénile

\section{RÉSUMÉ}

On trouva des taux des immunoglobulines augmentés dans les sérums des 47 patients atteints de polyarthrite rhumatoïde juvénile (IgG en 34 per cent., IgA en 36 per cent. et IgM en 53 per cent. des cas respectivement) par rapport aux chiffres trouvés chez 12 sujets sains. La distribution de la séropositivité pour les facteurs rhumatoïdes chez des patients atteints de polyarthrite rhumatoïde juvénile fut la même chez les porteurs de immunoglobulines augmentées et chez ceux dont le taux des immunoglobulines était normal.
Las inmunoglobulinas séricas en la poliartritis reumatoide juvenil

\section{SUMARIO}

Cifras aumentadas de inmunoglobulinas fueron encontradas en los sueros de 47 pacientes con poliartritis reumatoide juvenil (IgG en un 34 por ciento, IgA en un 36 por ciento y IgM en un 53 por ciento de los enfermos, respectivamente) en comparación con las cifras en 12 sujetos sanos. La distribución de la seropositividad respecto a los factores reumatoides en enfermos con poliartritis reumatoide juvenil fué igual en los enfermos con cifras de inmunoglobulinas elevadas y en los con cifras normales. 